\title{
Optimization of plant nutrition in the system of factors of efficient soil fertility
}

\author{
Baliuk S. ${ }^{1}$, Nosko B. ${ }^{2}$, Shymel V. ${ }^{3}$, Yeterevska L. ${ }^{4}$, Momot H. ${ }^{5}$ \\ NSC «A.N. Sokolovsky Institute for soil science and agrochemistry research», Chaikovska Str., 4, Kharkiv, \\ 61024, Ukraine; e-mail: ${ }^{1-5}$ pochva@meta.ua
}

The purpose. To determine mainstreams of optimization of plant nutrition, their interrelation with problems of soils' fertility. Methods. System analysis of printed materials and generalization of results of researches. Results. Primary factors of maintenance of optimization of nutrition of agricultural crops are resulted. Data concerning stocks of nutrition elements in arable layer of soils which characterize potential opportunities of these soils in maintenance of plants with nutrients are analyzed. The major factors which influence efficiency of fertilizers are determined. Results of $X$ round of selective agro-chemical certification are presented on security of soils of Ukraine with the main elements of nutrition. Dynamics of balance of nutrients in agriculture of Ukraine is shown. Role and value of optimization of application of mineral fertilizers increases in conditions of scarce balance of elements of nutrition (doze, ratio, ways of entering etc.). Main reasons of infringement of mineral nutrition of plants are systematized. It is noted that today special value gets efficiency of use of mineral fertilizers at simultaneous inclusion in system of fertilizer of local source of raw materials - organic fertilizers (vegetative rests, sapropels, peat, green manure crop etc.). It is noted that modern concept of rational application of fertilizers in a context of steady development of agricultural production should consider economic, social and ecological components. Basic organizational and agrotechnical factors influencing efficiency of use of fertilizers are determined, and system of actions aimed to prevention and termination of degradation processes in soils is offered. Conclusions. At regular scarce balance of nutrition elements in agriculture of Ukraine infringement of ratio of use of elements of nutrition from soil and fertilizers is observed. Increase of crops due to highly effective varieties and introduction of modern intensive technologies threatens preservation of effective soils' fertility, decreases content of mobile nitrogen and phosphorus because of accelerated mineralization of humus. The mainstream of increase of soils' fertility is optimization of elements of nutrition by implementation of organizational and agrotechnical measures, including alignment of balance of nutrients in agriculture, more efficient use of local sources of raw materials, adjustment of dozes and ways of application of fertilizers.

Key words: soil, nutrients, balance of elements of nutrition, fertility of soil.

DOI: https://doi.org/10.31073/agrovisnyk201903-02

Agricultural crops, especially modern intensive varieties, reveal their potential under the favorable conditions of the environment, first of all under optimal modes of nutrition and maintenance of moisture. The main source of nutrients for plants is the soils, primarily the nutrient content and their physical and physical and chemical properties, which provide the necessary for absorbing mobility of nutrition elements in main phases of development.

The task of agrochemistry (by D.M. Pryanyshnykov) is the study of the circulation of substances in agriculture and the identification of such factors of influence on chemical and biological processes in soils and plants that provide high productivity and product quality [1]. The main way to increase the intensity of this cycle is the use of fertilizers, taking into account the interaction in the system of fertilizer-soil-plant.

Aim of research - to determine the regularities of the influence of organizational and agronomic measures on optimization of plant nutrition.

Methods of research. The generalization of numerous publications, in particular leading authors, describing the most important methodological approaches to the optimization of plant nutrition, including the needs of plants in nutrient elements on soils with different their contents, the influence of physico-chemical and agrochemical indices of soil on the absorption of nutrients, the role of the ratio of available macro - and 
trace elements for their use, physiological features of different crops in the absorption of nitrogen, phosphorus and potassium from soil solution, fertilizer aftereffect and others.

Research results. Optimization of plant nutrition involves a set of interrelated organizational and technological measures aimed at providing agricultural plants with nutrition elements in quantity and ratio, which are necessary for obtaining the planned level of yield for minimizing ecological and economic risks, as well as the obligatory condition for preservation of soil fertility and obtaining proper sanitary-hygienic quality of products.

One of the main factors (requirements) for providing optimization of nutrition is the physiological need of separate crops in the elements of nutrition (macro-, meso- and microelements, their optimal ratio), which is determined by their biological characteristics (development of the root system and its interaction with soil solution, intensity growth, etc.).

Taking into account the law of minimum, optimum and maximum, the value of the crop depends on the growth factor of the plants that it restricts. It can be one of the elements of nutrition, and because of their sufficient amount of crop is limited by the lack of moisture and other factors that affect the crop, in particular, the physical and chemical characteristics of the soil - acidity, alkalinity, lack or insufficient amount of heat.

K.A. Timiryazev considered the law of the maximum and the interaction of factors of growth and development of plants one of the main laws of nature, and all the tasks of agriculture are in determining and obligatory maintenance of nutrition conditions of plants [2]. The stocks of nutrients in the arable layer of soils of Ukraine are: on nitrogen 8,7 - 2,4 t/ha, phosphorus $\left(\mathrm{P}_{2} \mathrm{O}_{5}\right)-5,4-1,3$ and potassium $\left(\mathrm{K}_{2} \mathrm{O}\right)-57$ 24 t/ha (Table 1).

1. Stocks of nutrients in arable layer of soils, $t / h a[3]$.

\begin{tabular}{|l|c|c|c|}
\hline \multicolumn{1}{|c|}{ Soils } & $\mathrm{N}$ & $\mathrm{P}_{2} \mathrm{O}_{5}$ & $\mathrm{~K}_{2} \mathrm{O}$ \\
\hline Chernozem ordinary medium-humus & 8.7 & 5.4 & 57 \\
\hline Chernozem ordinary low-humus & 7.2 & 5.7 & 39 \\
\hline Dark chestnut solonetz & 4.5 & 4.5 & 46 \\
\hline Chernozem typical low-humus & 5.4 & 6.9 & 50 \\
\hline Chernozem typical medium-humus & 10.8 & 5.1 & 52 \\
\hline Chernozem podzolized & 4.8 & 4.2 & 50 \\
\hline Dark gray podzolized & 4.5 & 3.9 & 50 \\
\hline Gray forest & 3.0 & 2.7 & 40 \\
\hline Light-gray forest & 3.0 & 2.7 & 40 \\
\hline Sod-podzolic sandy & 2.4 & 1.3 & 24 \\
\hline
\end{tabular}

Gross stocks of nutrients characterize the potential of soil in providing plants with nutrients. A close correlation between the gross volume and the amount of moving nutrients and the efficiency of mineral fertilizers is established. Their payback with the increment in yield increases on less fertile soils (sodpodzolic sandy compared with loamy chernozem). In most soils, total nitrogen stocks significantly exceed relevant indicators of phosphorus, especially in different subtypes of chernozem, which results in a rather high efficiency of phosphate fertilizer application.

The share of fertilizer use in the yield (on the example of winter wheat) ranges from $36 \%$ on soddy podzolic soils to $18 \%$ on chernozems. However, according to long-term studies, available nutrients in the soil (for each type of fertilizer) represent a small fraction of gross reserves (the content of mobile phosphorus does not exceed $3-5 \%$, and the content of mineral nitrogen, even in rich chernozem, depends on weather conditions).

The most important factors influencing fertilizer efficiency include: agrochemical properties of soils (mainly, the stocks of nutrients available to plants); climatic conditions (the growth of a crop from fertilizers on one type of soil may depend on humidity and continental climate); the level of previous fertilization (the effect of fertilizers increases in areas of prolonged use of soils without fertilizers and, conversely, weakens on the background of their systematic application); agrotechnical measures that promote the mobilization of 
natural reserves of nutrients or cause changes in the needs of plants (irrigation, drainage, cultivation, weed control, crop rotation, accumulation of residual phosphates, etc.). [4].

The modern concept of rational use of fertilizers in the context of sustainable development of agricultural production should take into account economic, social and environmental components. In the rational system of application of fertilizers, we take into account 4 main rules: the form of fertilizer, the dose, the timing and methods of application. Efficiency of fertilizers is influenced by many other factors: genetic features of soils, in particular granulometric composition, zonation of soil-climatic conditions, including fluctuations of humidity and temperature, genetic indices of modern varieties, weeds control, methods of cultivation of soil, etc.

According to the summarized data, mineral fertilizers provide incremental yields in the Polissya area at the level of $40-60 \%$, Forest Steppe - 30-50 and Steppe - 10-30\% without irrigation and up to $60-80 \%$ for irrigation. In addition, mineral fertilizers affect the mobilization of nutrients in soils, the quality of products, soil properties, and reduce the cost of moisture on the formation of products.

The results of the $X$ round of selective agrochemical certification regarding the provision of soils in Ukraine by the main elements of the nutrition are given in Table. 2. According to the content of easily hydrolyzed nitrogen, available forms of phosphorus and potassium, soils with low and average parameters predominate. At the same time, the zonal features are clearly identified: from all the nutritional elements Polissya soils are distinguished, in which the least distribution of areas with a high content of mainly nitrogen and potassium is observed. Soils with medium and high levels of phosphorus and potassium predominate in Ukraine. The growth of the content of mobile phosphorus in soils is due to its positive balance in 1970-1990, which contributed to the accumulation of residual phosphates.

2. Provision of soil with the main elements of nutrition

(According to the $\mathrm{X}$ round agrochemical certification)

\begin{tabular}{|l|c|c|c|c|}
\hline \multirow{2}{*}{$\begin{array}{c}\text { Level of } \\
\text { provision }\end{array}$} & \multicolumn{3}{c|}{ Area of soils, thousand hectares } \\
\cline { 2 - 5 } & $\begin{array}{c}\mathrm{N} \\
\text { easily } \\
\text { hydrolysed }\end{array}$ & $\begin{array}{c}\mathrm{P}_{2} \mathrm{O}_{5} \\
\text { mobile }\end{array}$ & $\begin{array}{c}\mathrm{K}_{2} \mathrm{O} \\
\text { mobile }\end{array}$ & $\begin{array}{c}\mathrm{S} \\
\text { mobile }\end{array}$ \\
\hline Very low & 7486.8 & 445.2 & 335.6 & 1314.5 \\
\hline Low & 7627.5 & 1534.9 & 1251.0 & 3155.2 \\
\hline Medium & 885.6 & 7125.2 & 3334.4 & 3663.4 \\
\hline Increased & 231.5 & 5934.7 & 5724.1 & 1673.0 \\
\hline High & - & 2798.0 & 5189.7 & 965.0 \\
\hline Very high & - & 1212.6 & 3215.7 & 858.4 \\
\hline
\end{tabular}

The use of modern high-intensity varieties in agricultural production and the implementation of means for controlling weeds, pests and plant diseases contributed to the growth of yield (mainly exportoriented) crops, which is not accompanied by the sufficient removal of mineral and organic fertilizers. Against this backdrop, for the period 1996-2015, there was a negative balance of nutrient elements (Table 3), which leads to the spread of degradation processes, primarily to active dehumidification of soils.

3. Dynamics of balance of nutrients in agriculture of Ukraine

\begin{tabular}{|l|c|c|c|c|}
\hline \multirow{2}{*}{ Item of balance } & \multicolumn{4}{|c|}{ Balance of nutrients, kg active substance /ha } \\
\cline { 2 - 5 } & nitrogen & phosphorus & potassium & NPK \\
\hline Supply & 89.5 & 56.1 & 102.7 & 248.3 \\
\hline Removal & 92.6 & 31.2 & 103.2 & 227.0 \\
\hline Balance & -3.1 & 24.9 & -0.5 & 21.3 \\
\hline
\end{tabular}




\begin{tabular}{|c|c|c|c|c|}
\hline \multicolumn{5}{|c|}{$1996-2000$} \\
\hline Supply & 26.0 & 10.4 & 15.3 & 51.7 \\
\hline Removal & 56.5 & 18.2 & 53.7 & 128.4 \\
\hline Balance & -30.5 & -7.8 & -38.4 & -76.7 \\
\hline \multicolumn{5}{|c|}{$2001-2005$} \\
\hline Supply & 21.8 & 5.9 & 8.7 & 36.4 \\
\hline Removal & 70.1 & 24.7 & 76.7 & 171.5 \\
\hline Balance & -48.3 & -18.8 & -68.0 & -135.1 \\
\hline \multicolumn{5}{|c|}{$2006-2010$} \\
\hline Supply & 38.7 & 10.2 & 14.7 & 63.6 \\
\hline Removal & 77.4 & 23.9 & 60.3 & 161.6 \\
\hline Balance & -38.7 & -13.7 & -45.6 & -98.0 \\
\hline \multicolumn{5}{|c|}{$2011-2015$} \\
\hline Supply & 65.0 & 13.1 & 18.1 & 96.2 \\
\hline Removal & 85.0 & 25.5 & 33.2 & 143.7 \\
\hline Balance & -20.0 & -12.4 & -15.1 & -47.5 \\
\hline
\end{tabular}

It was exported with exported grain in the 2016-2017 marketing year: nitrogen-811 thousand tons, phosphorus -302 , and potassium -211 thousand tons. To compensate for these losses, it is necessary to applicate: ammonium nitrate -2.4 million tons, ammophos - 0,58 million tons and potassium salts $-0,53$ million tons.

Thus, large agroholdings receive a significant portion of profits through the use of soil resources and violate natural laws, in particular the law of compulsory compensation (fully) for extracted nutrients from the soil. This leads to intensive dehumidification of soils, since $95-97 \%$ of nitrogen and about $50 \%$ of phosphorus are in the organic part of the soil, and their absorption by plants requires enhanced mineralization of humus. And if we always neglect of the law of obligatory return of nutrients, that were removed with yield, the soils will completely disappear in the near future, and even the most fertile chernozem will stop providing any yield, especially against the background of deteriorating climatic conditions.

The level of application of mineral fertilizers in different countries varies from $10-12$ to $400-600 \mathrm{~kg} / \mathrm{ha}$ of active substances (an average of more than $100 \mathrm{~kg} / \mathrm{ha}$ ). Ukraine is ranked 102th place among the average annual fertilizer rates. In 1986-1990, the use of mineral fertilizers averaged almost $150 \mathrm{~kg} / \mathrm{ha}$ of active substances on an area of about $90 \%$ of arable land. In addition, during these years, one put $8.8 \mathrm{t} / \mathrm{ha}$ of organic fertilizers. Mineral fertilizers were applicated in the ratio $\mathrm{N}: \mathrm{P}: \mathrm{K}=1: 0.7: 0.7$, which was approximated to a scientifically grounded level.

In 1996-1998, the amount of removed mineral fertilizers decreased to $20-30 \mathrm{~kg} / \mathrm{ha}$, and by 2015 2017 it increased to $80-110 \mathrm{~kg} / \mathrm{ha}$ of the active substance in the area of $80 \%$ of arable land at a ratio of $\mathrm{N}: \mathrm{P}: \mathrm{K}=1: 0.2: 0.2$.

It should be noted that during these years, the predominance of nitrogen fertilizers in the ratio 1:0.2:0.2 ensured their high payback due to accumulated in soil a significant amount of residual phosphates, since on the poor on the content of soluble phosphorus soils the effectiveness of nitrogen fertilizers is reduced. However, this resource (the content of residual phosphates in soils) is now decreasing due to the shortage of phosphorus in agriculture in Ukraine.

According to the calculations of the NSC "Institute for Soil Science and Agrochemistry Research named after O.N. Sokolovsky", a deficit-free nutrient balance requires a consistent increase in fertilizer application to $130-150 \mathrm{~kg} / \mathrm{ha}$ of active substance NPK. To do this, it is necessary to applicate 3,500 thousand tons of mineral fertilizers for the ratio $N: P: K=2,2:(1,0-1,2):(0,7-0,8)$. Obviously, in the coming years, the level of application of mineral fertilizers at the same time increase their value neither agroholdings nor farms will not be able to achieve. In this context, the effectiveness of using mineral fertilizers becomes very important while simultaneously application into the fertilizer system local raw materials - organic fertilizers, plant residues, sapropels, peat, siderates and others. One of the areas of use of local raw material resources in agriculture is the production of organo-mineral fertilizers. The scientific institutions of the NAAS 
have developed technologies for the production of organo-mineral fertilizers based on local raw materials with the addition of NPK and trace elements. To improve the nitrogen and phosphate nutrition of plants should be widely used bacterial agents. The average amount of biological nitrogen intake from the application of biological agents is about $20 \mathrm{~g} \mathrm{~kg} / \mathrm{ha}$ [5].

Under conditions of the deficit of nutritional elements in agriculture in Ukraine, the role and importance of optimizing the use of mineral fertilizers (dose, ratio, methods of application, etc.) is increasing. According to generalized data, this can provide up to $30 \%$ savings for fertilizer without reducing the yield increment.

We systematized the main causes of the violation of mineral nutrition of plants, namely: imbalance of nutrients, non-maintenance of crop rotation, adverse weather conditions (temperature, drought), leaching of easily soluble forms of nutrients, antagonism of elements in the soil, physiological inaccessibility due to high osmotic pressure, adverse changes in properties of soils - $\mathrm{pH}$, alkalinity, as well as the aftereffect of residues of herbicides and other xenobiotics.

Scientific institutions developed and applied various methods for diagnosing the content of nutrients in soils and plants, and the zones of application of these methods were determined. The levels of nutrient elements $\mathrm{N}, \mathrm{P}$ and $\mathrm{K}$ were established. Soil technologies were developed taking into account the content of nutrients in the soil, crop rotation, methods of cultivation, adaptation to climate change, etc. [6-15].

The generalized results of field experiments show a special influence of optimization of plant phosphate nutrition on the efficiency of fertilizers. With the use of a single $\left(\mathrm{P}_{60}\right)$ and a double dose of phosphorus fertilizers on the background of NK, the maximum increase in the winter wheat yield is provided (from 3.5-5.4 to 5.7-12.5 centners per hectare on chernozems with a natural phosphorus content of $4.5-5.5$ $\mathrm{mg}$ of $\mathrm{P}_{2} \mathrm{O}_{5}$ per $100 \mathrm{~g}$ of soil.

High fertility phosphorus payback by increment in yield on the natural phosphate background (6-9 kg of grain per $1 \mathrm{~kg}$ of $\mathrm{P}_{2} \mathrm{O}_{5}$ ) is reduced at high phosphate levels from 2.7 to $0.3 \mathrm{~kg}$ of grain (Table 4).

4. Payback of phosphate fertilizers by the increment of winter wheat grain on chernozems with different phosphate level

\begin{tabular}{|c|c|c|c|c|c|c|}
\hline \multirow{4}{*}{ Variant } & \multicolumn{6}{|c|}{ Increment of grain on $\mathrm{kg} \mathrm{P}_{2} \mathrm{O}_{5}$ to background $\mathrm{NK}, \mathrm{kg}$} \\
\hline & \multicolumn{2}{|c|}{ podzolized } & \multicolumn{2}{|c|}{ typical } & \multicolumn{2}{|c|}{ ordinary } \\
\hline & \multicolumn{2}{|c|}{$\mathrm{P}_{2} \mathrm{O}_{5}, \mathrm{mg} / 100 \mathrm{~g}$} & \multicolumn{2}{|c|}{$\mathrm{P}_{2} \mathrm{O}_{5}, \mathrm{mg} / 100 \mathrm{~g}$} & \multicolumn{2}{|c|}{$\mathrm{P}_{2} \mathrm{O}_{5}, \mathrm{mg} / 100 \mathrm{~g}$} \\
\hline & $4.4-5.5$ & $13.0-14.0$ & $4.7-5.2$ & $12.5-13.5$ & $4.2-4.7$ & $13.0-14.0$ \\
\hline $\mathrm{P}_{60}$ & 5.7 & 0.3 & 9.0 & 1.5 & 5.8 & 2.7 \\
\hline $\mathrm{P}_{120}$ & 2.5 & 0.0 & 5.4 & 3.0 & 3.9 & 2.0 \\
\hline
\end{tabular}

Phosphorus plays an extremely important role in all metabolic processes in plant cells, in particular in the accumulation of bound water, which contributes to increasing the resistance of crops to stressful conditions associated with climatic changes [16].

Increasing the agrochemical background of soils contributes not only to increasing the yield stability to unfavorable moisture conditions, but also to more economical water consumption by 1 centner of manufactured products. According to the research results, evapotranspiration (total evaporation of water by soil and plants) on a high agrochemical background grows significantly less than crop yields, while water consumption per 1 centner of the crop of basic products on these backgrounds is decreasing. In extreme climatic conditions, with a decrease in the amount of precipitation during the vegetation period of $120 \mathrm{~mm}$ from average long-term data, water consumption per 1 centner of dry matter of maize is $5.5 \mathrm{~m}^{3}$, and sugar beets $9.7 \mathrm{~m}^{3}$ smaller on the increased phosphate background (8-8,5 $\mathrm{mg} \mathrm{P}_{2} \mathrm{O}_{5}$ per $100 \mathrm{~g}$ soil) compared to the natural background (control variant with content of $4.0-4.5 \mathrm{mg} \mathrm{P}_{2} \mathrm{O}_{5}$ per $100 \mathrm{~g}$ soil).

One of the important directions for the effective use of fertilizers (especially phosphorus) is the local method of their application. NSC ISSAR established that the use of mineral fertilizers was locally compared with the spreading method, the yield of winter wheat increased by 3 centners per hectare, and maize for grain - by almost 10 centners/ha for the same doses of fertilizers [17]. 


\section{Conclusions.}

In the agriculture of Ukraine during the last 27 years, the soils are under the influence of a negative balance of nutrients, which violates the main law of agriculture, which requires the full return of the removed nutritions with yield. Increasing yields at the expense of highly efficient varieties and the implementation of modern plant protection technologies from weeds, diseases and pests threatens the effective fertility of soils, as it leads to a decrease in the content of mobile nitrogen and phosphorus due to accelerated humus mineralization.

Soil organic matter contains $95-97 \%$ of nitrogen and about $50 \%$ of phosphorus, which can be used by plants only after mineralization of humus. Agrophysical, physico-chemical properties of the soil, its structure, etc. are related to humus.

Under conditions of insufficient quantity of mineral fertilizers to increase their efficiency, to calculate their doses it is necessary taking into account agrochemical characteristics of the soils of each field, and also to apply more rational ways of application. An important role in increasing the effective fertility is the application of organo-mineral fertilizers and bacterial preparations.

\section{References}

1. Pryanishnikov D.N. (1952). Izbrannyie sochineniya.[Selected Works]. Issue 3. Moscow: Izdatelstvo AN SSSR, 630 p. [in Russian]

2. Timiryazev K.A. (1948). Zemledelie i fiziologiya rasteniy.[Agriculture and Plant Physiology]. Moscow: Selhozizd, 424 p. [in Russian]

3. Nosko B.S. (2013). Azotnyi rezhym gruntiv i yoho transformatsiia v ahroekosystemakh. [Nitrogen regime of soils and its transformation in agroecosystems]. Kharkiv: KP «Miska drukarnia». 130 p. [in Ukrainian].

4. Nosko B.S. (1990). Fosfatnyi rezhym gruntiv i efektyvnist dobryv. [Phosphate soil regime and fertilizer efficiency]. Kyiv: Urozhai, 220 p. [in Ukrainian].

5. Nosko B.S. (1999). Shliakhy pidvyshchennia rodiuchosti gruntiv u suchasnykh umovakh silskohospodarskoho vyrobnytstva. [Ways of increasing fertility of soils under modern conditions of agricultural production]. Kyiv: Agrarian Science, 110 p. [in Ukrainian].

6. Nosko B.S. (2017). Fosfor u gruntakh i zemlerobstvi Ukrainy. [Phosphorus in soils and agriculture of Ukraine]. Kharkiv: FOP "Brovin D.V.", 476 p. [in Ukrainian].

7. Baliuk S.A., Medvedev V.V., Nosko B.S. (2018). Adaptatsiia ahrotekhnolohii do zmin klimatu: gruntovo-ahrokhimichni aspekty. [Adaptation of agrotechnologies to climate change: soilagrochemical aspects]. Kharkiv: Stylna typohrafiia, 364 p. [in Ukrainian].

8. Truskavetskyi R.S., Tsapko Yu.L. (2016). Osnovy upravlinnia rodiuchistiu gruntiv. [Fundamentals of soil fertility management]. Kharkiv: FOP "Brovin D.V.", 388 p. [in Ukrainian].

9. Baliuk S.A., Miroshnychenko M.M. (2016). Systemy udobrennia silskohospodarskykh kultur u zemlerobstvi pochatku XXI stolittia. [Systems of fertilization of agricultural crops in agriculture at the beginning of the XXI century]. Kyiv: Alfa-steviia, 400 p. [in Ukrainian].

10. Hadzalo Ya.M., Kaminskyi V.F. (2016). Naukovi osnovy vyrobnytstva orhanichnoi produktsii v Ukraini. [Scientific bases of production of organic products in Ukraine]. Kyiv: Agrarian science, 592 p. [in Ukrainian].

11. Baliuk S.A., Truskavetskyi R.S., Tsapko Yu.L. (2012). Khimichna melioratsiia gruntiv (kontseptsiia innovatsiinoho rozvytku). [Chemical soil reclamation (concept of innovative development)]. Kharkiv: Miskdruk, 129 p. [in Ukrainian].

12. Natsionalna dopovid pro stan rodiuchosti gruntiv Ukrainy (2010). [National report on soil fertility in Ukraine] Kyiv: VIK-PRINT LLC, 111 p. [in Ukrainian].

13. Zaryshniak A.S., Lisovyi M.V. (2008). Suchasni systemy udobrennia silskohospodarskykh kultur u sivozminakh z riznoiu rotatsiieiu za osnovnymy gruntovo-klimatychnymy zonamy Ukrainy. [Modern fertilizer systems of agricultural crops in crop rotation with different rotation in the main soil-climatic zones of Ukraine]. Kyiv: Agrarian science, 120 p. [in Ukrainian]. 
14. Baliuk S.A., Zaryshniak A.S., Lisovyi M.V. (2013). Ahrokhimichne zabezpechennia zemlerobstva Ukrainy na period do 2020 roku (kontseptualni polozhennia). [Agrochemical provision of agriculture of Ukraine for the period up to 2020 (conceptual provisions)]. Kharkiv: Miskdruk, 58 p. [in Ukrainian].

15. Zaryshniak A.S. (2015). Optymizatsiia udobrennia ta rodiuchosti gruntu v sivozminakh. [Optimization of fertilization and soil fertility in crop rotations]. Kyiv: Agrarian science, 208 p. [in Ukrainian].

16. Iglesias A., Garrote L., Quiroga S., Moneo M. (2009). Impacts of climate change in agriculture in Europe. PESETA-Agriculture study, $53 \mathrm{p}$.

17. Fateev A.I. (2002). Lokalnyiy sposob vneseniya udobreniy. Pochvenno-agrohimicheskie aspektyi. [Local method of fertilizer application. Soil-agrochemical aspects]. Kharkiv, 160 p. [in Russian]. 